\title{
The Main Obstacles and Possibilities of the Cooperative Movement in Lithuania
}

The article analyses the obstacles of the cooperative movement in Lithuania and proposes new insights for the development of their activities. Analysis was based on and carried out using the Delphi survey methodological approach. The experience of a transnational Association of Producers Organisation "First International Association Fruit" was investigated as a relevant example. Suggestions for the development of Lithuanian cooperatives were worked out.

Keywords: globalisation, cooperatives, development, Association of Producer Organisation.

Straipsnyje analizuojamos pagrindinès Lietuvos kooperatyvų vystymosi kliūtys, siūlomos naujos jų veiklos plètros perspektyvos. Analizè buvo atliekama taikant Delfi tyrimo metodologinị požiūrị. Tyrinèjama tarptautinès gamintojų organizacijų asociacijos First International Association Fruit veiklos patirtis. Parengti Lietuvos kooperatyvų plètros pasiūlymai.

Raktiniai žodžiai: asociacija, gamintojų organizacijos, globalizacija, kooperatyvai, vystymasis.

\section{Introduction}

Cooperatives are organizational forms where: (a) the beneficiaries of the goods or services produced by the organization also have ultimate decision-making power; (b) not only the owners but also employees, suppliers and/or customers could be the inestors; and (c) organizational governance typically does not discriminate among members in terms of rights having typically a one person/one vote rule (Diaz-Foncea, Marcuello, 2013). The cooperative movement in all post-communist countries has so far been slow (see among others Gubeni, 2000; Zinovchuk, 2001; Kozuch and Koloszko-Chomentowska, 2006; Melnikiene, Vidickiene, 2006). After the restoration of independence on March $11^{\text {th }} 1990$, no cooperatives had been established for a long time due to the absence of legislation. The number of cooperatives grew after the promulgation of the Cooperative Law of the Republic of Lithuania in 1993 (LR Kooperatinių bendrovių (kooperatyvu) itstatymas, 1993 (The Law of the Cooperatives of the Republic of Lithuania)). Since 1993, the total number of agricultural cooperatives in Lithuania actually has not been changing from year to year, therefore, at the end of 2012, there were merely about 200 cooperatives. The share of cooperatives in the agricultural market has been small and only dairy producers have been selling about 30\% of their production through cooperatives.

Julius RAMANAUSKAS - doctor of social sciences, professor at the Faculty of Social Science, Department of Management, Klaipeda University. Address: H. Manto g. 84, Klaipėda, Lithuania. Phone: +37046 398666. E-mail: juliuss. ramanauskas@gmail.com.

Rimantas STAŠYS - doctor of social sciences, professor at the Faculty of Social Science, Department of Management, Klaipeda University. Address: H. Manto g. 84, Klaipeda, Lithuania. Phone: + 37046 398676. E-mail: rimantas.stasys@ ku.lt.

Francesco CONTÒ - doctor of social sciences, professor at the Department of Economics, University of Foggia. Address: Largo Papa Giovanni paolo II, 1 Foggia, Italy. Phone: + 390881 781817. E-mail: francesco.conto@unifg.it. 
In $2007,44 \%$ of the farmer cooperatives consisted of only five members while only seven cooperatives had more than 500 members. About three quarters of the cooperatives had open membership policy, some applied entry criteria, and $8 \%$ were closed to new applicants. In one out of twelve cooperatives the Board of Directors (consisting on average of five members) included non-member professionals. In accordance with the law of Lithuania, cooperatives had a one-tier board structure (Bijman et al., 2012).

Despite the substantial national and European support, a large number of registered organisations did not really function for the reasons such as: farmers were not well informed about the benefits of cooperatives; there was a lack of cooperative management knowledge, a lack of skillful and educated cooperative managers, and a number of phycological barriers, i.e., farmers had no trust in management, had deeply rooted individualistic thinking and unwillingness to change business habits (Čaplikas, Ramanauskas, 2001; Pareigienè, Ribašauskienė, 2008). Therefore, it is important to identify and eliminate these causes and contributing factors in order to solve economical and social probelms in the rural areas associated with the development of cooperatives. Undoubtedly, the traditional theory of cooperatives (Baltramijūnas, 1938; Fauquet, 1938; Šalčius, 1989; Tugan-Baranovskij, 1989; Chajanov, 1919) should be revised as it does not comply with the changes taking place in economic globalisation. Economic globalisation and its development resulted in the growing competition, expansion of the former internal national markets (products were crossing the borders of both the EU and other countries), appearance of large production and trade corporations in the market, and the threat of cheaper products entering from the Eastern countries.

The basic principles of cooperatives differ from the philosophy of other collective enterprises. Such principles as the necessity for cooperative members to participate in the activity of the enterprise (to have a turnover), independence, election to and removal from the positions or bodies of management, democratic control (one member - one vote), non-commercial character of activity, and limited investment income are typical exclusively only to cooperatives. However, it is not always necessary and good to observe the old cooperative principles, as their unconditional observance may prevent (and does prevent) from establishment of new organisation forms and entrepreneurship development. Therefore, a case study of Lithuania is considered to be a good example. Economic changes have been taking place in Lithuania like in the rest postcommunist countries, therefore, there is an obvious need for a new scientific approach to the traditional principles of agricultural cooperatives (Ramanauskas, Stašys, 2011).

The present paper aimes to analyse the current activity of contemporary Lithuanian cooperatives giving insights and suggestions for their development in order to underline future challenges. The article is organised as follows: the next section aims to describe the role of cooperatives in the agricultural sector and the situation of cooperativism in all post-communist countries, especially in Lithuania; section 2 is dedicated to the methodological approach; section 3 describes results highlighting the obstacles of the cooperative movement in Lithuania; section 4 provides an example based on the transnational Association of Producer Organisations. Finally, the authors present policy suggestions and conclusive remarks. 


\section{Literature review}

The European Commission notices cooperatives as a means to raise the economic rule of SMEs, as a mechanism to provide high quality services to groups that otherwise would not have access to them; in addition, cooperative models can be a source of entrepreneurial and management opportunity (European Commission COM, 2004). In other words, how a cooperative assumes a user-benefit, userowned, and user-controlled economic organizational structure (Barton, 1989), even if cooperatives seem to function like ordinary enterprises (Hendrikse, 2007). In summary, the term cooperative, as a rule, is followed by two characteristics listed below:

- a cooperative is a social movement of farmers that seeks to reduce unemployment, to improve the education of farmers and their professional training, to improve their living and cultural level, to create conditions for farmers to have more free time, vacations, etc.;

- a cooperative is an organisational-legal form of an enterprise that has economic goals and does not actually deal with social problems (Ramanauskas, 2007).

Some authors argue that a cooperative can be categorized by how ownership rights are defined and assigned to economic agents tied contractually to the firm (Cook, Chaddad, 2004); others highlight the hybrid form of a cooperative thanks to a market-like attributes with hierarchylike mechanisms by using a comparative economic perspective (Chaddad, 2012).

Besides the form and category, it is to be noted that agricultural cooperatives assume a relevant economic role in agri-food chains and have strong market positions, for example, in US, being increasingly involved in upstream and downstream stages (Chaddad, 2010; Chaddad, Cook, 2012; Karantininis, Nilsson, 2007). Cooperatives are forming more and more alliances and joint ventures with other cooperatives in order to improve rural network and to face the international competitiveness (Chaddad, 2010).

In fact, agricultural cooperatives have been changing considerably in the last years assuming unusual ownership-control models that influence the organisational efficiency of cooperatives (Chaddad, Iliopoulos, 2013) and they have faced crucial changes in competition and distribution of the market power of agrifood chains; so cooperatives have been continuously adjusting in their strive for competitiveness, innovation, and survival (Karantininis, Nilsson, 2007).

In the light of the global market liberalization that is creating innovative paths to produce, distribute and consume food, cooperativism and its several possible models can assume a crucial and strategic role in enhancing local resources by creating a network between their members to reinforce member loyalty (Filippi, 2014). In this context, it becomes necessary to develop relationships and trust within value chains (Fischer, Hartmann, 2010). Social embeddedness of interrelations allows transactions to take place: social connections between firms based on trust, reliability and reciprocity can create intangible and unique resources which enhance firms' competitiveness (Hartmann et al., 2010).

In the next section, we present an overview of cooperativism in Lithuania. As the literature shows there have been several studies carried out related to cooperative 
forms but we can notice some scientific gaps related to the actual situation of cooperativism form in Lithuania. Indeed, so far no theory has been substantiated that could offer prerequisites for the development of agricultural cooperatives under the new circumstances.

\section{Cooperatives in Lithuania}

In the course of time and in different historical periods, changes took place in the development of cooperatives in Lithuania. The social (democratic) and economic goals of the first cooperatives were concurrent (and in some cases, social goals even predominated). For a long time, economic goals served as means for the solution of social problems and only afterwards, in the fight against the capitalist enterprises they acquired increasing importance. Incidentally there are quite a few people who have memories of cooperatives as small, local enterprises that would unite rural farmers with the aim of addressing social issues.

Globalisation as any other phenomenon has both positive and negative impacts. The positive impacts include: icreased trade, income, spread of democracy and knowledge, but on the other hand, globalisation spurs braindrain, corporate influence on governments, pollution. Globalisation has influence on the Baltic States' exports competitiveness: in order to be competitive in a global market, producers in the Baltic States have to take into consideration a lot of aspects, such as production costs, product differentiation, level of quality, currency rates (Masteikienè, Šliburytè, 2010). Under such circumstances, cooperatives had to be economically strong and competitive, therefore, economic motives started prevailing over the social ones. Currently, cooperatives in Lithuania are founded based on one of the key economic principles, such as the economies of scale; indeed the economies of scale and scope as well as in transaction costs can be captured by the cooperatives (Altman, 2015). Mergers of farmers and cooperatives, possessing a large quantity of products, have a better chance to sustain a more distinguished part of the market and become more competitive.

The increase in the world population and the global economy require large consumption of natural resources and this creates too much waste at the end of the production cycle; therefore, environmental issues are becoming more important and that is why the activities of cooperatives are to be evaluated not only in accordance with the economic and social but also with the environmental criteria.

Although in Lithuania, like in some other EU member countries, dairy (in Lithuania $25 \%$ of the cooperative market share), fruit and vegetable chains are the predominant sectors together accounting for $60 \%$ of all the agricultural product market produced by the cooperatives (Bijman et al., 2012); yet credit unions take a significant place in the development of cooperatives in Lithuania too. A reliable financial system is necessary to successfully develop agriculture. It is not accidental that cooperation in Germany and many other countries, including Lithuania, started with the establishment of the Cooperative Credit Unions. All the other cooperatives emerged later. It is known that the income in agriculture, differently from other manufacturing enterprises, is received very inconsistently due to the long production period needed for agricultural 
products. The funds are not used during certain periods, however, for the most part, there is a shortage of funds. Due to numerous reasons, commercial banks do not fully satisfy needs of farmers, therefore a more reliable and flexible financial system is needed. Moreover, there is a need to establish legal grounds in order to ensure the development and creation of agricultural credit cooperatives and to support the initial loan capital. The solution of the problem would enable to build a favourable lending system, which would lead farmers to successful development of their businesses having the low loan expenses.

In this context, credit unions are the most important form of a cooperative in Lithuania that significantly support agricultural cooperatives. A credit union is a member-owned financial cooperative (Ryder, Chambers, 2009), democratically controlled by its members, and operating for the purpose of promoting thrift, providing credits at competitive rates, and providing other financial services to its members. Members join according to certain general criteria and manage a credit union democratically, in accordance with the existing law.

The basic elements of a credit union are the following (Lietuvos Respublikos kredito unijų istatymas, 2000):

- credit union policies are based on the principle of cooperatives; it is a nonprofit organisation without outside investors. Union members are the owners of the organisation, each having a vote. The annual profit can be distributed among the union members based on the member's capital turnover;

- credit union members are a certain group of people who should obtain shares and thus become the owners of a credit union;
- policy-building executive bodies are elected from the union-members leaders on a volunatary basis;

- the Board of Directors, Loan Committee, and Supervisory Committee are elected during the annual member meetings, and the Union Administration is hired.

It is worth mentioning that credit unions still mainly provide short term loans to their members as they are not able to accumulate enough funds for the long term investment loans. Credit unions primarily satisfy the needs of their members: mainly private persons and less frequently legal entities. Credit union loans are relatively expensive because their assets make approximately only 0.1 percent of the total assets of all the loan organisations system. Despite that, credit unions are becoming serious competitors for commercial banks in the rural areas.

The Lithuanian Central Credit Union that supports the solutions of general lending problems within the country was established in 2001. This credit organisation, structured on the cooperative principles, was established by the Lithuanian Government and was registered under the law of Lithuania. It works on the basis of share capital and supports credit unions' solvency and payment recovery functions, receives deposits from its members, as well as repayable funds, provides loans and assumes the risks and responsibility associated with all those key functions. Currently, more favorable conditions have been created for the credit unions enabling them to provide more operations, and public confidence in them has been increasing. The Stabilization Fund has been established seeking to provide assistance to the credit unions that encounter solvency problems. It is very important that credit 
unions can participate in the deposit insurance system, which allows them to raise more money and increase the volume of mutual loans and other activities.

The Lithuanian cooperative movement is gaining momentum. During 2008-2012, the number of members in credit unions increased by $52.2 \%$, assets grew $158.7 \%$, and loans and deposits increased respectively by $89.7 \%$ and $205.6 \%$ (Jasevičienè, Mačiulis, 2014). At the end of 2013, there were 73 credit unions (Liutinskienè, 2014) and over 100 units (otherwise known as "remote" branches) in various villages and towns in Lithuania. By their nature and conditions, credit unions are financial institutions in local communities, however, they operate in a common financial market, which is strongly influenced by the globalisation and consolidation processes, together with large commercial banks. During the recent years, the importance of credit unions in the Lithuanian banking market has been constantly growing, yet their development trends and prospects have not been widely analysed in the scientific literature. Still, credit unions' leaders are optimistic about their future success prospects. Positive and negative factors having impact on the development of credit unions have to be constantly analysed, and the analysis should be taken into consideration to ensure further development of credit unions in Lithuania. Credit unions, together with the organisations and authorities representing them, play a very important role in the cooperative education and legal regulation of this area.

Social cooperatives are established in order to satisfy social, cultural, educational, and other needs of their members. Social cooperatives can thus be seen as a type of a social enterprise, and they continue to represent one of the most developed and successful models of a social enterprise (Borzaga et al., 2014). Therefore, one can open a cooperative day care, various training schools or book stores (widely known book sale within the USA universities) or other similar institutions. For example, in Sweden at the beginning of the last century, housing cooperatives were established and even a cooperative federation was created for these types of cooperatives. Cooperatives can help to build houses or apartments for their members, especially younger ones, at a lower cost. Such cooperatives perform a wide range of activities: maintain the environment; take care of the elderly, disabled, and children, or manage utilities. As a result, specialised cooperatives have been established: some organise recreation for the members, as they have their own recreation infrastructure (tourist bureaus, hotels, camping grounds, transportation, etc.), others provide funeral services, etc. Those types of cooperatives are not likely to expand in Lithuania in the nearest future. They face similar obstacles as other cooperatives. It is expected that some of the objectives of social cooperatives will be implemented by larger cooperatives of different kinds.

\section{Methodology}

The analysis presents the outcomes of the long-time research which focused on external and internal factors and conditions that essentially affected the activity of cooperative businesses in Lithuania. The analysis was carried out by the means of the Delphi survey methodological approach, a method for consensus-building, by using questionnaires delivered in multiple iterations in order to collect data from a panel of 
selected subjects (Hsu, Sandford, 2007). The survey was perfor-med from February to October in 2014. Experts were interviewed during the visits to selected cooperatives, during training seminars for farmers within the "Agricultural Cooperatives" program organised by the Agriculture Ministry of Lithuania and funded by the $\mathrm{EU}$, or during consultations with farmers.

Discussions took place with the heads and specialists of Danish, Latvian, Polish, Dutch, and Swedish cooperatives. In addition, the EU regulations were studied, national and foreign scientific and other literature, togerther with legislation, was examined and summarised, which resulted in the analysis of different national farms and cooperatives. Qualitative research was carried out in order to define the main obstacles preventing a successful development of the cooperatives in Lithuania. A form of semi-structured interviews delivered in multiple iterations was chosen. Additional and unplanned questions were presented during the research. Interview questions were designed with the goal to find the answers to the existing research goals so there were three key sets of questions: social, economic and environmental barriers within the development of the cooperatives.

During the interviews, qualitative data (answers to open-ended questions) were accumulated. The key questions included: Why do cooperatives in Lithuania start and develop slowly? What are the obstacles for the development in your cooperative? How would you rate the opportunity and the necessity of sustainable development of your cooperative? What criteria would you propose for the evaluation of sustainable development? What are the most effective measures to be taken for the sustainable development of a cooperative?
Qualitative research used the evaluations of national experts - heads or members of cooperatives. In the qualitative research, expert assessments, i.e., interviews with Lithuanian farmers, the heads of the companies (Agro Neveronys, Minija, Kauno šiltadaržiai, Kèdainiu gèlès, Kietaviškiu gausa), as well as the heads of the currently operating or no longer operating agricultural cooperatives (Agrohansa, Agrolit, Aviža, Biodyzelis, Bulviu namai, Daržoviu centras, Kuršiu kraštas, Lietuviškas pienas, Nešpa, Pienas LT, Pieno gèlè, Plungè-Loiret, and many others) were used. Research participants were selected by the convenience sampling. The key criterion was that participants had to have at least five year experience working in a cooperative. Experts from 26 cooperatives participated in the survey: 17 cooperative managers and 9 cooperative members-farmers.

\section{Results}

Our analysis shed some light on the characteristics of activity of contemporary Lithuanian cooperatives in order to propose insights and solutions for their development. The vast majority of the experts agreed that the social significance of cooperatives is less important, even though they acknowledged that these organisations increase the number of jobs, make it easier to organise professional development for employees and cooperative members, and improve the level of their performance, recreation, and culture.

In response to the question, "What do you think of the necessity for cooperatives to observe environmental regulations?", all the respondents noted that the environmental protection measures were necessary; however, they should be observed 
as much as they complied with the requirements of the hygiene standards, as well as the requirements for the national and the EU support as prescribed by the rules of support. Nevertheless, the experts agreed that the merger of farmers into the cooperatives created an opportunity to expand the cultivation of organic products (as the production of large amounts made it easier to find a market), to look for the ways of the use renewable energy sources, to introduce energy-saving technologies, and to master and to apply the latest scientific achievements.

Under the new conditions, slow development of cooperatives and failures in their activities are frequently explained by certain obstacles, such as lack of funds, faulty taxation, etc. As proved by the research, the elimination of some, even the most significant, obstacles failed to produce the expected result: it was necessary to eliminate their cumulative impact on the development of the cooperative movement. We shall name some key obstacles typical of the period: it will be difficult to expect the successful development of the cooperative movement unless these adverse factors are eliminated (Figure 1).

1. A shortage of well-trained managers. The role of the manager in the success of the cooperative has been emphasized by the majority of scholars and has been demonstrated by practice. The roles of the board (council) and the administration of the cooperative are equally important. It is obvious that the members of the cooperative, its Council, and its administration shall only be able to perform their functions effectively if they are qualified and experienced. Unfortunately, to date there is a lack of such specialists in Lithuania.

2. No theory has been substantiated so far that could offer prerequisites for the development of agricultural cooperatives

\begin{tabular}{|c|c|}
\hline & 1. The absence of well-trained managers \\
\hline & 2. Insufficient theoretical substantiation \\
\hline & 3. The absence of a co-operative system \\
\hline & 4. The principle "one member - one vote" \\
\hline & 5. Inappropriate organisation of funding \\
\hline The obstacles to the starting and & 6. The absence of the methodology of planning, accounting, and accountability \\
\hline & 7. Observation of the "non-profitability" principle \\
\hline & 8. Funding with other than one's own funds \\
\hline & 9. Encountering the difficulty of "hard" competition \\
\hline & 10. A fear of starting a common economic entity \\
\hline & 11. A fear of losing the farming independence \\
\hline & 12. Insufficient co-operative education \\
\hline
\end{tabular}

Fig. 1. The principal obstacles to cooperative movement 
under the new circumstances. The circumstances are preconditioned by the specificity of the agricultural system and the processes of globalisation. The diversity of the farm sizes is one of the important characteristics of the Lithuanian agricultural economy and it significantly impacts the activity of the cooperatives. Along with a small number of large-scale farmers and agricultural cooperatives that have several hundred hectares of land, numerous herds of cattle, and large areas of greenhouses, there are thousands of small producers (two to three hectares) whose share in the total production of individual products is rather significant. Economically strong and technologically advanced large-scale farmers and agricultural companies are not interested in collaboration with small producers. Therefore, it is necessary to develop a theoretical model for the collaboration of small- and large-scale farmers.

3. The absence of a system of cooperatives or of their associations is one of the problems in the development of cooperatives. We propose setting up a territorial system that would bring together local, regional, and national cooperatives. An important place should be taken by cooperative unions (associations) that in Lithuania would perform not merely political functions but would also represent the economic interests of the members of the cooperatives: would undertake commercial-economic activities (the production of final products, the supply of machinery and equipment, the search for investments and markets, the trade, the provision of information, etc.). Most importantly, the organisation of such associations would provide an opportunity to unite small and large scale farmers for common activities.
4. The democracy of the governance is one of the most serious problems in the cooperative movement. As is known, democracy is based on the principle "one member-one vote", i.e., each member regardless of his turnover in the cooperative and the invested capital has one vote. However, some types of cooperatives where the number of votes depends on the number of shares do exist in the developed countries. That is largely determined by economic issues and then the danger arises that in the case of renunciation of the compulsory turnover and democratic principles the cooperative will lose its uniqueness, i.e., it will neglect democratic principles, however, it will cope with economic problems better.

Incidentally, in the period between the two world wars, the number of delegates to the meetings of the dairy cooperatives in Lithuania depended on the amount of butter produced by the company (one representative for each 20 tons of butter), i.e., the higher the turnover rate the larger the number of representatives (votes). The number of delegates was not restricted by any other terms.

It has to be noted that currently the "large-scale" members who own the lion's share in the cooperative business start demanding more votes and more influence. That is why the classical principle of the cooperation "one member - one vote" in a number of countries is no longer observed. The issue whether it would be more reasonable to renounce such a state of things is considered in order to attract more economically strong members of the cooperative. For example, Iceland has a regulation allowing the cooperatives to independently decide on the criteria of compensations for their members: on the basis of greater participation in the 
advancement of the material and technological infrastructure of the cooperative or on the basis of increasing its financial resources. In Belgium and Greece one can also see the trend of deviation from the position one member - one vote.

5. Inadequate organisation of the financing of cooperatives is another significant problem. Even though the most important objective of the cooperatives is satisfying member needs and creating favorable conditions for credit terms, product storage, processing, marketing, and services, cost-effectiveness of the company activity is also of utmost importance for them. Such conditions can only be provided by the competitive and large cooperatives, which are more advanced to compete with other companies and useful for a lot of farmers, however these cooperatives do have sufficient financing. Therefore, creation of such an enterprise or the expansion of its activity is not profitable. The creation of the farmer cooperatives could be supported by the state or other physical or legal persons who are interested in the success of those cooperatives, however they do not have any turnover with a cooperative enterprise. However, according to the Law on the Cooperative Societies (Cooperatives) of the Republic of Lithuania such persons shall not be members of the cooperative. Consequently, there is no legal basis for the investments from outside. Moreover, direct investments (or loan guarantees) that the investors cannot properly control are risky. The problem could be solved by the means of commandite cooperatives (Ramanauskas, 2007). Public authorities, banks, various foundations, joint stock companies, private individuals, etc., could act as commanditaires. Commandite cooperatives would accelerate and facilitate the development of the agricultural cooperatives and their activities and simultaneously eliminate a number of problems existing in agriculture; however, to date, they have not been legalized in Lithuania. Providing the members of the cooperative with the right of purchasing shares is another solution to financing the cooperatives. Such an opportunity exists in numerous countries.

6. The absence of methodology of planning, accounting, and accountability is a grave issue related to cooperatives in Lithuania. Cooperatives frequently underestimate the importance of planning and tend to unreasonably optimistically forecast their activities without taking into account potential risks; they do not use the advice of the consultants for the drafting of scientific forecasts.

7. It is necessary to update some cooperative principles by adapting them to the conditions of globalisation. In the light of those changes, it is also necessary to revise the Law on the Cooperatives. A classical "non-profitability" principle of cooperatives may have a negative effect on the acquisition of reliable partners for individual cooperatives and on setting up their associations in the market conditions. Therefore, at present the majority of the cooperatives in the world seek to make a profit and to set up various foundations; individual members receive bonuses and get social benefits; the money per share is calculated differentially, etc. The principle of "democratic governance" was logical for the cooperatives whose main objective was just to cope with the social problems. However, given that the main objective is to cope with the economic problems, the majority of the votes (as well as the majority of the profit) should belong to the members who collaborate with the 
cooperative most closely, i.e., who have the greatest turnover rate. The principle of "non-profitability" may not be implemented if an individual cooperative prefers to merge with a large enterprise or to coordinate its activities with other legal forms of enterprises. If the principle is changed the key issues in the large organisations shall be dealt by the representatives delegated by the members for the participation in elections, for the control of the administration, etc.

8. In response to the question, "What are the obstacles to the development of your cooperative?", most of the respondents reported that a number of cooperative members did not consider the cooperative enterprise to be "their brainchild". That was because their contribution to the setting up of this enterprise was insignificant and the monetary contributions came not from its members-farmers but rather from the state or the EU funds. The use of personal (or borrowed) funds is of special importance as it makes the cooperative members share the true ownership and start to appreciate it, to take an active part in its activities, and to sell all their produce exclusively through their own enterprise (even if other companies offer slightly higher prices). However, that condition, as a rule, is ignored, despite the fact that the violation of the said principle is one of the key reasons of why created cooperatives fail and close. Notable examples of bankruptcy in Lithuania of large milk processing enterprises that were set up "on a cooperative basis" (and actually on public funds), as well as of vegetable selling or technical services (agricultural services) cooperatives ought to be carefully considered. The experience should not be forgotten even presently when cooperatives are set up with EU funds as opposed to the funds of the agricultural producers.

9. The start of the cooperative activity is restricted by "hard" competition. Historically, at the beginning of the previous century cooperatives were set up without any competition with the other companies. That way, credit, land reclamation, selection, insurance, technical maintenance, and other cooperatives were founded (the only exception was the trading cooperatives, which even as early as in ancient times were set up by facing the resistance of the private trading networks). Currently, however, cooperatives may be starting their activities under the conditions of an unfavorable state of the market. A huge number of well-equipped, market-possessing enterprises function in the country and the competition with them is problematic. Newly created cooperatives find it difficult to gain a foothold next to other enterprises, formerly state-owned and later re-organized at the time of privatization (joint-stock companies or others), which have a substantial material basis. Difficulties in the access to markets and in the consolidation of positions account for one of the major reasons for the insufficient development of the agricultural cooperatives. Thus, in addition to the principal objective of a cooperative, i.e. to provide services to its members, it is very important to ensure the cost-effectiveness of its activities which guarantees success in a competitive environment.

10. It is noteworthy that farmers tend to feel mutual distrust and a fear of starting a common economic entity. Mutual distrust and a fear of being misled also hinder the development of the cooperatives. The outcomes of a farmer survey witness that they do not think they 
have reliable neighbours they could collaborate with. For that reason, it is difficult to start, e.g., a cooperative of technical services and especially to bring people together for the joint acquisition of new equipment.

11. Farmers are afraid to lose their independence and because of this rather ungrounded reason they avoid co-operation. As proved by the surveys, cooperatives as form of farming are often associated with the relic of the former regime, i.e. they are totally unjustifiably associated with the soviet collective farms (kolkhoz). Farmers have a fear of the creation of common property and common work. The fact is often ignored that once the decision is made to start a cooperative, its members also create an economic entity: a joint venture which helps them to solve common problems. The members of the cooperative enterprises provide the produce grown by them, hire professionals for product processing, and implement or provide farmers with other services (e.g., technical). In that classical schema, common work of farmers is absent. The only common solutions to the farmers' postproduction problems are processing the produce grown by them and delivering the production to a customer under favorable conditions. The schema is used by farmers all over the world; therefore mutual trust of the farmers is not a decisive factor for cooperative activities. Cooperative members should be guided by economic and social purposes not by emotions.

12. Both farmers and initiators of cooperatives as well as peope in general still do not have sufficient knowledge of cooperatives and their specific characteristics. Quite a lot of errors are made when starting cooperatives their accounting (especially related to the member shares) is inappropriate. The acceleration in the cooperative development largely depends on the popularization of the idea of co-operation and the correct understanding of its essence. The more people understand that cooperatives are the most realistic measure in the de-monopolization of the agricultural market and the establishment of the equality of agricultural producers, the more people understand that without cooperatives small agricultural enterprises will not be able to survive in the market conditions and the support from the state will not be effective the sooner they will become crucial supporters of the cooperatives. That calls for cooperative education of the population and verbal and written information on the radio, TV, and the Internet.

Lithuanian farmers encounter all of the above described obstacles. Moreover, for the successful cooperative development they need more contemporary buildings and equipment, the reduction of the high energy costs, and more investments into the modernization of the production facilities. Lithuanian cooperatives could overcome these obstacles by setting up a transnational Association of Producer Organisation.

\section{A transnational Association of Producer Organisations: an example for Lithuanian cooperative movement}

Alliances and joint ventures are more and more popular among cooperatives in promoting rural interrelation/network and dealing with the international competition (Chaddad, 2010). The experience of a transnational Association of Producer 
Organisation, F.In.A.F ("First International Association Fruit"), has been analysed as a potential solution to the successful development of interrelated cooperatives in Lithuania.

A transnational Association of Producer Organisations (APO) is an association of producers' organisations consisting of different EU member countries. F.In.A.F ("First International Association Fruit") is one of the first transnational APOs. The aggregation experience is the result of the cooperation between the Italian PO 'Apoconerpo' and the French PO 'Conserve Gard'. The association includes some of the main products in the sectors of fresh and processed fruits (conserves) in the related regions. The objectives of the Association are defined in line with the requirements established by the European Commission and can be summarised as follows (EU, 2011):

- designing, planning, and implementation of an Operational Programme;

- concentration of supply and placing on the market of the products produced by its members;

- optimising production costs;

- $\quad$ stabilising producer prices;

- ensuring that production is planned and adjusted to demand, particularly in terms of quality.

The promotion of the Association of Producer Organisation at an international level allows the development of "hybrid" forms of cooperation, ensuring at the same time:

- autonomy: the aggregation form allows the preservation of autonomy and identity of individual companies that will participate;

- aggregation: the association's size is consistent to the needs of international competition.
International competition, economic and financial crisis of 2008-2009 has amplified the traditional difficulties of the production systems based on the small and medium-size enterprises. Therefore, on one hand smaller size cooperatives are more flexible and dynamic and, on the other hand, they are not able to sustain competitive advantage in the current global competitive landscape where more structured and bigger players operate. Thus, small cooperatives have to take advantage of economies of scale and invest in the processes of innovation and internationalization. Additionally, there is a prospect of a sluggish domestic demand (Contò et al., 2013). Due to their flexibility and adaptability, transnational Associations of Producer Organisations can contribute to the different dimensions of sustainable development (see Table 1) and increase competitiveness in Lithuania. In addition, they can function as "a fundamental building block of agriculture for-development agendas" as stated by the World Bank Development Report, Agriculture for Development (2007).

The transnational Association of Producer Organisations represents a very important innovation for the competitiveness of the national production systems as it improves the relationship between businesses and regions allowing entrepreneurs to deal with the market changes. It is an extremely flexible instrument in which companies decide on aspects of cooperation without special requirements for the legal form of business, the size of an organisation, the area of the cultivated land, or the geographical locality and which, unlike some other ways of "entering into competition", has the advantage of preserving the autonomy of individual members. 
International APO functions and contributions to sustainable development

\begin{tabular}{|c|c|}
\hline Functions & $\begin{array}{l}\text { Sustainable Development } \\
\text { Dimensions }\end{array}$ \\
\hline Improving the terms of access to output and input market. & Economic \\
\hline $\begin{array}{l}\text { Supporting generation and adoption of technological } \\
\text { innovations and diversification into new activities. }\end{array}$ & Economic \\
\hline $\begin{array}{l}\text { Fostering collaboration among different stakeholders } \\
\text { in the value chain. }\end{array}$ & Economic \\
\hline Assuring quality and safety of food products. & Economic, Environment and Social \\
\hline Contributing to natural resource management. & Environment \\
\hline $\begin{array}{l}\text { Fostering participatory governance, particularly in relation } \\
\text { to decentralization and to community-driven development } \\
\text { approaches. }\end{array}$ & Social Inclusion \\
\hline $\begin{array}{l}\text { Participating in trade negotiations and in European } \\
\text { agricultural policy-making. }\end{array}$ & Economic, Environment and Social \\
\hline
\end{tabular}

\section{Conclusions}

Not so many cooperatives have been founded (about 200) since the restoration of the independence in Lithuania and their share in the overall market is low. However, credit unions have spread widely (currently over 72 credit unions and over 100 of their branches operate in Lithuania).

The key obstacles for the establishment and development of cooperatives Lithuania are of economic nature (weak financial capacity of farmers, adverse market conditions, unfavourable credit conditions, and a faulty taxation system), and of managerial nature (a shortage of leaders and the lack of the entrepreneurial and special knowledge), while others are of legal nature (a need to improve the Cooperative Law, given the contemporary agricultural structure and market conditions) or lie at the social psychological level (individualism, the absence of partnership or trust in oneself and others).
In addition to traditional cooperatives, new structures in the vertical integration of business, i.e., vertical business groups, are becoming increasingly important. They will unite agricultural producers (their cooperatives), processing enterprises, financial and insurance organisations, research institutions, international trade organisations, and others. While participating in large business groups, cooperatives have to operate within the framework of modernised principles:

- in order to attract more economically strong members into cooperatives, it is necessary to abandon the principle of "one member - one vote", and moreover, in the development of regulations, to allow cooperatives independently decide on the voting procedure;

- the classical "non-profitability" principle of cooperatives may have a negative impact on some cooperatives in finding reliable partners, setting up associations, etc. In the present context, 
the principle of "non-profitability" should be applied merely to cooperatives of social orientation.

In summary, management and policy implications have to be directed to the expansion of the cooperative activity in Lithuania by means of:

- revision of the traditional cooperative theory and legislation;

- development of study programmes in agricultural colleges and universities for the training of cooperative specialists;

- inclusion of a compulsory course of the Fundamentals of Cooperatives in the competence development programme for young farmers seeking to obtain the EU and national support;

- development of instruments to activate the establishment of a transnational Association of Producer Organisation for sustainable agricultural and rural development.

\section{References}

1. Altman, M. (2015). Cooperative Organizations as an Engine of Equitable Rural Economic Development // Journal of Co-Operative Organization and Management. Vol. 3, Issue 1, June, p. 14-23. doi: 10.1016/j.jcom.2015.02.001.

2. Baltramijūnas, S. (1938). Kooperatinis auklèjimas, švietimas bei propaganda. - Kaunas: Lietuvos kooperatyvų taryba.

3. Barton, D. G. (1989). What is a Cooperative? In D. W. Cobia (Ed.). Cooperatives in Agriculture. - Englewood Cliffs, NJ: Prentice Hall.

4. Bijman, J., Iliopoulos, C., Poppe, K. J. et al. (2012). Support for Farmers' Cooperatives. Final Report. Internet access: <http://ec.europa.eu/ agriculture/external-studies/support-farmerscoop_en.htm> [accessed December 15, 2016].

5. Borzaga, C., Bodini, R., Carini, C., Depedri, S., Galera, G., Salvatori, G. (2014). Europe in Transition: The Role of Social Cooperatives and Social Enterprises // Euricse Working Papers. No. 69 (14).

6. Čaplikas, J., Ramanauskas, J. (2001). Kooperacijos raida ir perspektyvos Lietuvos žemès ūkyje // Vagos. Nr. 49 (2), p. 63-70.

7. Chaddad, F. (2012). Advancing the Theory of the Cooperative Organization: The Cooperative as a True Hybrid // Annals of Public and Cooperative Economics. No. 83 (4), p. 445-461. doi: 10.1111/j.1467-8292.2012.00472.x.

8. Chaddad, F. R., Cook, M. L. (2004). Understanding New Cooperative Models: An Ownershipcontrol Rights Typology // Review of Agricultural Economics. No. 26 (3), p. 348-360. doi: 10. 1111/j.1467-9353.2004.00184.x.
9. Chaddad, F., Cook, M. (2012). The International Cooperative Movement: A Quiet Giant./In P. Battilani \& H. Schröter (Eds.). The Cooperative Bu-siness Movement, 1950 to the Present (Comparative Perspectives in Business History). - Cambridge: Cambridge University Press. doi: 10.1017/ CBO9781139237208.010.

10. Chaddad, F., Iliopoulos, C. (2013). Control Rights, Governance, and the Costs of Ownership in Agricultural Cooperatives // Agribusiness. Vol. 29 (1). p. 3-22. doi: 10.1002/agr. 21328.

11. Chaddad, F., Rodriguez-Alcalá, M. E. (2010). Inter-organizational Relationships in Agri-food Systems: A Transaction Cost Economics Approach. / In Fischer, C., \& Hartmann, M. (2010). Agri-food Chain Relationships. - Oxford: CAB International. doi: 10.1079/978184593642 6.0045 .

12. Chajanov, A. V. (1919). Osnovnye idei i formy organizacii krest'janskoj kooperacii. - Moskva: Izdanie Soveta Vserossijskih Kooperativnyh 5 ezdov.

13. Contò, F., Fiore, M., La Sala, P. (2013). Organization and Structure of the Chain, in Integrated Projects for the Food Chain in the Region of Basilicata: The Effects on the New Rural Dynamics // PAGRI/IAP. No. 3, p. 77-85.

14. Cook, M. L., Chaddad, F. R. (2004). Redesigning Cooperative Boundaries: The Emergence of New Models // American Journal of Agricultural Economics. No. 86 (5), p. 1249-1253. doi: 10. 1111/j.0002-9092.2004.00673.x. 
15. Diaz-Foncea, M., Marcuello, C. (2013). Entrepreneurs and the Context of Cooperative Organizations: A Definition of Cooperative Entrepreneur // Canadian Journal of Administrative Sciences. No. 30 (4), p. 238-251. doi: 10.1002/cjas.1267.

16. European Commission. (2011). Directorate-General for Agriculture and Rural Development. No. 2. Internet access: <http://ec.europa.eu/agriculture/fruit-and-vegetables/producer-organisations/ibo_en.pdf $>$.

17. Fauquet, G. (1938). Kooperatinis ūkio sektorius. - Kaunas: Lietuvos kooperatininkų sektorius.

18. Filippi, M. (2014). Using the Regional Advantage: French Agricultural Cooperatives' Economic and Governance Tool // Annals of Public and Cooperative Economics. Vol. 85 (4), p. 597-615. doi: 10.1111/apce.12053.

19. Fischer, C., Hartmann, M. (2010). Agri-food Chain Relationships. - Oxford: CAB International. doi: 10.1079/9781845936426.0000.

20. Gubeni, Ju. (2000). Restitucija kak vazhnyj jelement agrarnoj reformy v Cheshskoj Respublike // Jekonomika Ukrainy. No. 11, p. 79-0085.

21. Hartmann, M., Hoffmann, J., Simons, J. (2010). Behavioural Economics and the Theory of Social Structure: Relevance for Understanding Inter-organizatio al Relationships / In Fischer, C., \& Hartmann, M. Agri-food Chain Relationships. - Oxford: CAB International. doi: $10.1079 / 9781845936426.0061$.

22. Hendrikse, G. (2007). Two Vignettes Regarding Boards in Cooperatives versus Corporations Irrelevance and Incentives / In Karantininis, K., \& Nilsson, J. Vertical Markets and Cooperative Hierarchies: The Role of Cooperatives in the Agri-food Industry. - Holland: Springer. doi: 10. 1007/1-4020-5543-0_8.

23. Jasevičienè, F., Mačiulis, D. (2014). Kredito unijų veiklos analizé // Ekonomika ir vadyba: aktualijos ir perspektyvos. Nr. 1 (33), p. 17-31.

24. Karantininis, K., Nilsson, J. (2007). Vertical Markets and Cooperative Hierarchies: The Role of Cooperatives in the Agri-food Industry. Holland: Springer.

25. Kozuch, A., Koloszko-Chomentowska, Z. (2006). A New Look at the Agricultural and Rural Cooperative Movement // Management Theory and Studies for Rural Business and Infrastructure Development. No. 1 (7), p. 77-80.
26. Lietuvos Respublikos kredito unijų i̇statymas (2000). Valstybès žinios, 45-1289.

27. Liutinskienè, J. (2014). Credit Unions' System in Lithuania. The European Microfinance Network 11th Annual Conference in Lisbon on June 19th and 20th, 2014. Internet access: <http://www. emnconference.org/archives/lisbon2014/images/lisbon/Workshops_Outputs/Credit_unions_in_Lithuania.pdf> [accessed September 20, 2016].

28. LR Kooperatinių bendrovių (kooperatyvų) įstatymas (1993). Birželio 1 d. Nr. I-164. Internet access: <http://www3.lrs.lt/pls/inter3/dokpaieska. showdoc_l?p_id=478788 $>$ [accessed September 19, 2016].

29. Masteikienè, R., Šliburyte, L. (2010). Impacts of Globalization on Lithuanian Economic Growth // Economics \& Management. August, p. 288-294.

30. Melnikiene, R., Vidickiene, D. (2006). Knowledge Management based Agriculturas Co-operation Policy in Lithuania // Management Theory and Studies for Rural Business and Infrastructure Development. Vol. 1 (7), p. 90-93.

31. Pareigienè, L., Ribašauskienè, E. (2008). Kooperacijos plètros vertinimas // Management Theory and Studies for Rural Business and Infrastructure Development. Vol. 12 (1), p. 122-129.

32. Ramanauskas, J. (2007). Kooperacijos pagrindai. - Kaunas: Spalvu kalvè.

33. Ramanauskas, J., Stašys, R. (2011). Cooperative Performance Assessment based on the Sustainable Development Aspect // Proceedings: Rural Development 2011. Vol. 4 (2), p. 190-194.

34. Ryder, N., Chambers, C. (2009). The Credit Crunch - Are Credit Unions able to Ride out the Storm? // Journal of Banking Regulation. Vol. 11, p. 76-86. doi: 10.1057/jbr.2009.14.

35. Šalčius, P. (1989). Raštai: Kooperacija. - Vilnius: Mintis.

36. Tugan-Baranovskij, M. I. (1989). Social'nye osnovy kooperacii. - Moskva.

37. World Bank (2007). World Development Report 2008: Agriculture for Development. Washington: The International Bank for Reconstruction and Development // The World Bank. doi: 10.1596/978-0-8213-6807-7.

38. Zinovchuk, V. (2001). Organizacijni osnovi sil'skogospodars'kogo kooperativu. - Kiiv: Logos.

The paper submitted: March 10, 2017 Prepared for publication: May 30, 2017 
Julius RAMANAUSKAS, Rimantas STAŠYS, Francesco CONTÒ

PAGRINDINĖS KOOPERATYVU PLĖTROS LIETUVOJE KLIŪTYS IR GALIMYBĖS

$\mathrm{S}$ a $\mathrm{n} \mathbf{t} \mathbf{r}$ a u k a

Daugelis mokslininkų pastebi, kad kooperatinis judejjimas visose pokomunistinèse šalyse iki šiol yra lètas. Lietuvoje žemès ūkio kooperatyvų skaičius nuo 2000 m. iš esmès nesikečia. Kooperatyvų užimama rinkos dalis yra maža ir tik pieno gamintojai parduoda apie 30 proc. savo produkcijos per kooperatyvus. Nepaisant didelès nacionalinès ir Europos paramos, daug įregistruotų kooperatyvų dèl ịvairų kliūčių neveikia. Todèl kooperatyvų neveikimo priežasčių nustatymas ir pašalinimas yra viena iš pagrindinių problemų, ieškant būdų apsirūpinti maistu ir sprendžiant kaimo socialines problemas. Mokslininkų uždavinys - peržiūrèti tradicinę kooperatyvų teoriją, nes ji neatitinka pokyčių, vykstančių ekonominès globalizacijos laikotarpiu.

Pagrindiniai kooperatyvų veiklos principai skiriasi nuo kitų kolektyvinių įmonių principų. Čia veikia tik kooperatyvams tipiški principai: nariai turi dalyvauti įmonès veikloje (turèti apyvartą), demokratinis valdymas (vienas narys - vienas balsas), dažnai nekomercinis veiklos pobūdis ir ribotos investicinès veiklos pajamos. Tačiau laikymasis senų kooperatyvų principų dažnai gali trukdyti naujoms organizavimo formoms ir verslumo plètrai, todèl vykstantys ekonominiai pokyčiai reikalauja naujų mokslinių požiūrių ì tradicinius kooperatyvų principus.

Straipsnio tikslas - atlikus šiuolaikinių kooperatyvų veiklos analizę, pasiūlyti naujus sprendimus jų veiklos plètrai.

Straipsnyje analizuojama ir apibendrinta mokslinè literatūra ir teisiniai dokumentai kooperatyvų klausimais. Be to, vertinami nacionalinių ir tarptautinių ekspertų, kooperatyvų narių ir vadovų atsakymai. Nustatyta, kad kooperatyvų veikla vystosi lètai dèl ịvairių priežasčių: daugiausia susikuria maži kooperatyvai, kurie negali konkuruoti su didelèmis šiuolaikinėmis akcinėmis bendrovèmis, steigiant kooperatyvus neįvertinami Lietuvos agrarinès situacijos ypatumai (šalia stambių ūkininkų, žemès ūkio bendrovių yra ir daug mažų ūkių), kooperatyvai įsisteigia ir veikia pagal senus (tradicinius) principus. Vykstant globalizacijos procesams, reikia naujo mokslinio požiūrio ir kūrybiško tradicinių kooperatyvų principų ịvertinimo, kooperatyvų finansavimo.

Be tradicinių priemonių kooperatyvams rekomenduojama susijungti su akcinèmis bendrovèmis. Skatinant žemès ūkių tarpusavio santykius arba tinklus, igalinančius susidoroti su tarptautine konkurencija, tarp kooperatyvų populiarejja aljansai ir bendrosios i̇monès. Kaip galimas sprendimas Lietuvos kooperatyvų sèkmingai plètrai analizuojama tarptautinès gamintojų organizacijų asociacijos F. In. A. F. (Pirmosios tarptautinès vaisių asociacijos) patirtis. Taigi maži kooperatyvai turi pasinaudoti masto ekonomija, investuoti i inovacijas ir internacionalizavimo procesus. Taip susikurtų vertikalios verslo grupès, suvienijančios žemès ūkio produkcijos gamintojus (jų kooperatyvus), perdirbimo įmones, finansų ir draudimo organizacijas, mokslinių tyrimų institucijas, tarptautinès prekybos organizacijas. Siekiant pritraukti daugiau ekonomiškai stiprių narių ì kooperatyvus, būtina atsisakyti principo „vienas narys - vienas balsas“ ir leisti savarankiškai nuspręsti dẻl balsavimo tvarkos. Kooperatyvams rekomenduojama jungtis su užsienio kooperatyvais ir steigti tarptautines gamintojų organizacijų asociacijas. 